\title{
Examining the populist communication logic: Strategic use of social media in populist political parties in Norway and Sweden
}

Bente Kalsnes

ORCID: 0000-0002-8764-6925

OSLO METROPOLITAN UNIVERSITY, NORWAY

DOI: 10.19195/1899-5101.12.2(23).5

\begin{abstract}
Previous research has demonstrated that right-wing populist parties are particularly successful in gaining engagement and interaction on social media, but less is known about how rightwing populist parties use social media strategically, both in relation to voters and news media. By focusing on two Nordic countries, Norway and Sweden, this paper addresses the strategic use of social media within the Sweden Democrats and the Progress Party based on three different data sets: interviews, content analysis of Facebook posts, and engagement data from the parties' Facebook pages. This study finds that the two populist parties basically follow up their social media strategy in practice, and the Sweden Democrats are more closely following a populist communication logic in their Facebook posts. The article argues that right-wing populist parties' social media strategy and communication style must be understood in relation to their position in the political system and the parties' different phases in the life cycle model of populist parties.
\end{abstract}

KEYWORDS: social media, political communication, populism, election, Norway, Sweden.

\section{INTRODUCTION}

Social media have made it easier for political parties to bypass traditional, editorial media and reach out directly to supporters and potential voters. This opportunity is attractive for minor parties and parties in opposition with less access to news media compared to incumbent parties (Skogerbø \& Krumsvik, 2015). Previous research has demonstrated that right-wing populist parties are particularly successful in gaining engagement and interaction (i.e., shares and comments) on social media in the Nordic countries (Larsson, 2017). This confirms a tendency for 
right-wing parties to gain more traction in novel media spheres than in the coverage curated by established media actors (Lorentzen, 2014; Larsson, 2017).

Nevertheless, previous research has identified that there is limited systematic knowledge about the reasons for differences in the resonance of populist communication on social media (Engesser et al., 2016; Engesser et al., 2017), also in the Nordic countries (Jupskås et al., 2017). Studies have demonstrated how far-right movements have moved from "the street to the screens" (Bjørgo \& Gjelsvik, 2015, p. 48 [Author's translation of the Norwegian term fra 'gata' til 'data']) and social media has allowed far-right groups in Norway to mobilize and create interaction between sympathizers and activists within far-right movements (Haanshuus \& Jupskås, 2017). But less is known about how right-wing populist parties use social media strategically, both in relation to voters and news media. Similarly, Nordic populist parties have been examined in light of the life cycle model, which described the relationship between media and neo-populist movements (Stewart et al., 2003, pp. 219-224; Herkman, 2015), but social media was not taken into account in that examination. Nevertheless, such aspects will be addressed in this study, which examines what characterizes these two parties' use of social media during election campaigns in light of the life cycle model.

This study focuses on two Nordic countries, Norway and Sweden, and aims to contribute with insights into the digital strategic thinking within two so-called right-wing populist parties, The Progress Party (FrP) from Norway and Sweden Democrats (SD) from Sweden. Even though the two case countries could be described as most similar systems and as typical representatives of the Democratic Corporatist Model (Hallin \& Mancini, 2004; Strömbäck et al., 2008), the two rightwing populist parties have different characteristics and origin. They are also said to belong to different stages in the life cycle model (Herkman, 2015). The aim of the study is to address three main questions: (1) What kind of strategy do these parties have for social media and editorial media? (2) Are these parties' Facebook content characterized by the populist communication logic? (3) What type of engagement are the parties achieving on Facebook?

Thus, the study's task is three-fold. First, it examines strategy, secondly practice and thirdly response from followers on Facebook. Through a mixed method approach, this study will contribute with insights into how these parties strategically communicate in digital channels. The study aspires to contribute to the understudied field of populist parties' political communication on social media. In the next section, the study's theoretical framework will be discussed.

\section{POPULISM AND SOCIAL MEDIA}

Populism is a contested concept, and it has been interpreted as an ideology (Mudde \& Kaltwasser, 2017; Mudde, 2004), and as a particular style of communication (Aalberg et al., 2017; Engesser et al., 2017). Some of the defining characteristics of populism 
and populist parties are the perspective on the people and opposition to elites (Mudde, 2004; Albertazzi \& McDonnell, 2008). Mudde has defined populism as a "thin ideology that considers society to be ultimately separated into two homogenous and antagonistic groups, 'the pure people' versus 'the corrupt elite', and which argues that politics should be an expression of the general will of the people" (2004, p. 543). Additionally, populist parties are often described to embrace concepts such as popular sovereignty, the dangerous others and the heartland (Engesser et al., 2016). Populism can also be described as a communicative phenomenon: "media populism is the 'engine' of political populism, at least in the thin conceptualization of the "political communication style of political actors that refers to the people" (Mazzoleni, 2014, p. 53, citing Jagers \& Walgrave, 2007). Nevertheless, the changing nature of populism and national differences makes is hard to pinpoint a definition that neatly describes all populist parties or movements.

Recent contributions in political communication research have drawn attention to how populist parties are particularly successful when it comes to engaging with their followers on social media. Populist parties' intertwined and complex relationship to the people and to news media (Mazzoleni, 2014) could make social media platforms such as Facebook and Twitter even more promising for these parties. In a study of how politicians in four countries used Facebook and Twitter for populist purposes, the researchers found that "social media are particularly well-suited to meet the communicative preferences of populist actors and that they provide them with a convenient instrument to spread their messages" (Engesser et al., 2017, p. 1286). Internet and social media can be crucial for political parties to build a relationship with voters and potential supporters, for fundraising, to impact the news media's agenda and to mobilize and organize grassroots campaigns (Larsson \& Kalsnes, 2014; Kreiss, 2012; Klinger, 2013). Social media services such as Facebook and Twitter allow politicians to circumvent editorial news media and communicate directly with potential voters. The direct contact with large networks of people without the editorial news media as gatekeepers is attractive for politicians of all political leanings. Engesser et al. (2017, p. 11) have argued that four characteristics make social media highly compatible with populist communication: a direct access to the audience without journalistic interference, a close connection to the people, an infinite potential for personalization, and the possibility to target specific groups.

Social media allow for more direct and interactive contact with people compared to news media, a feature that, one could argue, is particularly attractive for populist parties (Mazzoleni, 2014). Due to social media platforms' characteristics both as medium and networks (Enjolras et al., 2013) - to publish and to connect people social media is appealing for political actors (Chadwick, 2013; Larsson \& Kalsnes, 2014). Social media platforms such as Facebook and Twitter have affordances or action possibilities (Gibson, 1979) that allow for different communication functions, such as broadcasting, distribution, interaction and acknowledgment (Boyd, 2010; Kalsnes \& Larsson, 2015, p. 221). These functions are available on Facebook and 
Twitter respectively as post/tweet, share/retweet, comment/mention, like/favorite. These affordances allow populist parties, as well as other political actors, to tap into the needs and demands of "the people," a crucial concern for populist parties (Engesser et al., 2016). Previous studies have demonstrated that political actors may benefit from using social media in a number of ways, particularly to disseminate information, mobilize supporters and run fundraising (Kalsnes, 2016b; Enli \& Skogerbø, 2013; Koc-Michalska et al., 2016).

Recently, the concept "populist communication logic" has gained some attention, which is defined as "the sum of norms, routines, and procedures shaping populist communication" (Engesser et al., 2017, p. 1280; Ihlebæk et al., unpublished work). Engesser et al. argue that populist communication logic consists of four main elements: ideology (content), actors (messenger), style (form), and strategy (motives and aims). Populist ideology is normally comprised of elements like people-centrism, anti-elitism, and the ostracizing of "others." (Engesser et al., 2017; Aalberg et al., 2017; Reinemann et al., 2017, p. 20). "The others" typically consist of "ethnic, religious, sexual, minorities" (Reinemann et al., 2017, p. 21). Secondly, populism is linked to a charismatic and strong leader as either a "constitutive" or "facilitative" element (Engesser, et al., 2017, p. 1284). By style the authors point to how ideas and political messages are communicated, and identify the use of simplification (reduction of complexity), emotionalization (anger, fear, resentment) and negativity (crisis, threat, unfairness) (ibid., p. 1285). Lastly, the authors refer to populism as a strategy meaning how a "populist actor uses populism as a means to an end" (ibid., p. 1286). Such aims could be to gain "power, legitimacy, and mobilization" or to "acquire and exercise power" (ibid.). Finally, populist communication logic is closely intertwined with the opportunities structures of the internet and social media.

This article examines whether content from the Norwegian and Swedish rightwing populist parties are characterized by the aforementioned populist communication logic. This paper will argue that it is not enough to look at the parties in isolation when examining the populist parties' social media and editorial media strategy, we also need to take into account their history and position in the political landscape. In order to do that, the two relevant parties will be examined in light of the life cycle model (Stewart et al., 2003).

\section{THE LIFE CYCLE MODEL IN THE NORDIC CONTEXT}

Populist movements' success is closely connected with media attention (Mudde, 2004), and this coexistence of populist parties and media behavior is a central element of the life cycle model of populist parties (Stewart et al., 2003). The life cycle model describes the relationship between mass media and populists in four phases: the ground-laying phase, the insurgent phase, the established phase, the decline phase.

The ground-laying phase is characterized by social and political discontent in a country, during which the media tend to create a negative and dramatic depiction of 
the domestic political situation, thus creating a political climate engendering neopopulist discourse (Stewart et al., 2003, pp. 219-221). The insurgent phase is characterized by intense media attention on the new neo-populist movement(s) because of the novelty, the messages, and the rhetoric (Stewart et al., 2003, pp. 221-222). During the established phase, the neo-populist movement has achieved public legitimacy and becomes a durable feature of the national political scene. In this phase, the volume of media attention normally shrinks, as the novelty has worn off. If the neo-populist movement really challenges the political status quo and social order, most media, especially elite media, will try to strengthen support for the ruling political parties through hostile coverage of the populists (Stewart et al., 2003, pp. 222-223; Herkman, 2015, p. 443). The decline phase refers to the fading of the neo-populist movement from the media, although not all movements confront this phase and may gain new success. Thus, media attention varies from country to country depending on the newsworthiness of the fall of the movement, or whether, for example, a new populist movement arises from the ashes of a former movement (Stewart et al., 2003, pp. 223-224). In Europe, this phase is not relevant to many European neo-populist movements because they "are still fairly successful and continue to receive significant media attention" as pointed out by Mazzoleni (2014, pp. 61-62) and Herkman (2015, p. 433).

The FrP from Norway and the SD from Sweden can be placed in two different phases, according to Herkman (2015). The two parties have different origins and characteristics, but both are labeled populist political parties in the research literature (Jungar \& Jupskås, 2014; Herkman, 2015). Nevertheless, the FrP is placed in the established phase while the SD is situated in the insurgent phase (Herkman, 2015, pp. 13-14). The FrP achieved, for the first time in Norway's history, a position in the government after the 2013 election (see Table 1 below). Together with the Conservative Party, the FrP constitutes what is called a blue-blue coalition. In Sweden, however, the political parties refused to cooperate with the SD, also after the party achieved $13 \%$ of the votes in the 2014 national election. In order to give an electoral context to the two parties' electoral position in the two recent elections as well as their campaign resources, I have compiled this overview (see Table 1).

While the Norwegian right-wing party emerged as an anti-tax protest movement in 1973 (Jupskås et al., 2017), the Swedish SD has roots in the neo-Nazi movement, which is frequently used to explain why the Swedish political establishment ostracizes the SD (Strömbäck et al., 2017). Despite the clear differences, the two Nordic parties have a strong anti-immigration policy in common. Additionally, both parties have performed successfully on social media in terms of creating engagement and interaction through likes, shares, comments and retweets (Larsson, 2017; Kalsnes, 2016b). The SD emerge as comparably successful on both Facebook and Twitter (Larsson, 2017). In the next section, I will outline the data and methods used in this study. 
Table 1. Electoral results, position and campaign resources for respectively the Progress Party and the Sweden Democrats in the 2013 election (Norway) and 2014 election (Sweden)

\begin{tabular}{|l|c|c|}
\hline \multicolumn{1}{|c|}{ Electoral party background } & The Progress Party & The Sweden Democrats \\
\hline $\begin{array}{l}\text { \% of votes in the previous national election } \\
\text { (year in parentheses) }\end{array}$ & $22.9(2009)$ & $5.7(2010)$ \\
\hline $\begin{array}{l}\text { \% of votes in the national election under } \\
\text { study (year in parentheses) }\end{array}$ & $16.3(2013)$ & $13(2014)$ \\
\hline In government after election & YES & NO \\
\hline Campaign budget 2013/2014 & 18 mln NOK & 8 \\
\hline $\begin{array}{l}\text { Number of people working with communi- } \\
\text { cation/web }\end{array}$ & 8 & 2 \\
\hline $\begin{array}{l}\text { Number of people working specifically } \\
\text { with social media }\end{array}$ & 1 & 2 \\
\hline
\end{tabular}

Source: interviews with the parties and https://valgresultat.no/?type=st\&year=2013 (accessed: 10.10.2017).

\section{METHODS}

The study is based on mixed methods and three datasets: semi-structured interviews with communication directors from the FrP and the SD ahead of the respective elections in 2013 (Norway) and 2014 (Sweden), content analysis of the parties' Facebook posts one month before the election ( FrP $N=57, \mathrm{SD} N=56$ ) and engagement data from the parties' open Facebook pages. The interviews were conducted with the head of communication in the $\mathrm{FrP}(\mathrm{NO})$ and head of communication in the SD (the names are anonymized in agreement with the informants). Both interviews were semi-structured and took place at their respective parliamentary offices at Stortinget (Norway) and Riksdagen (Sweden) some months ahead of the national elections. The interviews lasted for about 45 minutes. In addition, I also interviewed a social media manager in the FrP during their national convention. By reading and re-reading the interviews, following an inductive approach, I identified three main categories in the interviews: (1) social media's strategic role during the election campaign, (2) interactivity and (3) social media in relation to editorial media.

Secondly, this study is based on a content analysis of the parties' Facebook posts (FrP $N=57, \mathrm{SD} N=56$ ) during the same timeframe. The analysis builds on the framework for populist communication logic developed by Engesser et al., (2017, p. 1280), empirically employed by Ihlebæk et al. (unpublished work). In particular I examine the four main elements in the model: content, messenger, form, motives and aims. Within content, I look for expressions in the Facebook posts of popular sovereignty, people-centrism, anti-elitism and exclusion of "others." Within messenger, I look for expressions of a (charismatic) leader. Within form, I look for expressions of simplification, emotionalization, and negativity. Within motives and aim(s), I look for expressions of power, legitimacy and mobilization. 
Thirdly, this study is based on data from the parties' open Facebook pages. The parties' Facebook pages were analyzed in terms of different engagement measures such as likes, shares, comments, as well as replies from the party in the comment section. Data from the two parties' open Facebook pages were accessed and downloaded by using a web application called $f b \_l o a d e r$ (UiO 2013) developed by programmers at the University of Oslo. The web application, which was developed for this purpose, allows researchers to extract posts, comments and other interaction data such as likes and shares from public Facebook pages and study them according to different interaction measure. By measuring comments by page owner, which here means representatives from political party or party leader, it is possible to gauge the interactive responsiveness of political actors on Facebook. Data from the open Facebook pages of the two parties were collected six weeks before the election for both the parties. The national, parliamentary election in Norway took place on September 9, 2013, while it was held in Sweden on September 14, 2014. Basically, the data collection covers the short and most intense election campaign (Aardal et al., 2004).

\section{RESULTS}

\section{The strategic thinking behind the parties' social media use}

This study finds that both the FrP and the SD have clear preferences among the social network services, prioritizing Facebook ahead of other services such as Twitter, YouTube or Instagram. The combination of image, text and a huge network of followers is part of the explanation for the Facebook dominance. Facebook is the most popular social media platform in both Norway and Sweden (TNS Gallup), thus it makes it possible for the parties to reach out to more people.

There is actually only one real social media service, and that is Facebook.

The Sweden Democrats

Short, simple texts and understandable symbols is crucial in SD's communication strategy. "We want to make politics more understandable and interesting," according to the SD, who explains that Facebook works best with the combination of text and images.

Facebook is the place where we reach broadest.

The Progress Party

The FrP explains that there is a clear difference in the party's Facebook page and the party leader's Facebook page. While the party's page is more campaign oriented, the party leader Siv Jensen's page is more personal and run by herself. She posts images from dinners she attends or sports events she follows, personal moments she is willing to share. 
Both parties are aware of the distribution potential in social media, and to encourage likes and shares is crucial for the parties. Particularly shares is valuable because it spreads the message through friends-of-friends. Particularly the SD values shares highly:

Shares are the most important for us, it is our main priority. A like gives some spread, but a share gives the best spread.

The Sweden Democrats

The SD has observed that images with text is shared most extensively, news articles or videos are not shared so heavily. Sometimes they explain the image with some additional text in the post. Commenting on large news stories with sharp, critical comments or humor has also proved successful, according to the SD. Thus, humor can be a way for the party to increase the share count.

It has been crucial for the FrP to use analytics to track the popularity of Facebook posts - a lesson learned over the past few years. "If we don't get 200 likes on a post, we have failed," says the FrP. Through tools such as Hootsuite and Fanbooster, the FrP is tracking popular and less popular posts to grasp how people are reacting to their content.

If we should continue to use Facebook, we must use the tool properly and follow trends. We are tracking competitors all the time and we are also comparing the FrP with companies such as Telenor (telecom) and DNB (bank). When our leaders see our good results, it is easier to accept that we use resources on social media.

The Progress Party

The ambiguity towards Twitter is a commonality for the FrP and the SD. Twitter is mainly dominated by "media people," according to the SD:

We (the party) do not have an official Twitter account, but many of our politicians use Twitter. It is not the campaign's focus. Twitter in Sweden consists of a special group of people. There are many journalists, media people.

The Sweden Democrats

When asked why the party is not paying so much attention to Twitter, it is a combination of who is using Twitter and the technology:

Both the audience on Twitter and the technology. When Twitter arrived, it did not support images, now it works better with images. But the user groups who read Twitter are not relevant for us. Based on the party's interest, I don't see any large pay-off by using Twitter.

The Sweden Democrats 
For the Norwegian FrP, Twitter is used by the party and several of its leading politicians, but not by the party leader Siv Jensen.

Twitter is important for some of us. It is important for the party, but not for the party leader. It would be inauthentic if some of the advisors would tweet on Jensen's behalf, she would not accept that. But we do have politicians who are very active on Twitter, and who create good debates. Often, we get news stories out of it or are invited to participate in radio or $T V$ debates.

The Progress Party

\section{Dealing with interactivity in social media}

One clear difference between the two right-wing populist parties in Scandinavia is how they view comments and interactions on Facebook. While the SD downplays dialogue on social media, the FrP has clear ambitions to respond to their followers on Facebook.

Dialogue is not particularly important for us. We do have an ambition to have dialogue there (Facebook), it is good for dialogue, but our main goal with Facebook is to reach new people and voters. We do have some "trolls" (in the comment section) who are only interested in disturbing. It is actually better that our forum (Facebook page) functions as a meeting space, where sympathizers can talk to each other, they don't have to talk to us.

The Sweden Democrats

The SD is removing content from the comment sections, as well as blocking individuals for expressing threats or cruel things about people in or associated with the party.

We are deleting a lot. We are also blocking many individuals. We are forced to do it. It is leftist people.

The Sweden Democrats

The FrP has a bit of a different take on interactivity. They agree that the volume of comments can be overwhelming, often between 500-900 comments in a short timeframe on the party leader's page. Nevertheless, they try to respond and answer questions. But the need to moderate and delete comments is clear and present.

If there are trolls, swearing and threats, we will moderate. We are not deleting comments that are critical towards the FrP's policy, that's fine, it can create more debate. 
But clearly, we don't want one side to yell at the other. We are trying to get a serious debate thread.

The Progress Party

The FrP has used ideas or suggestions from the comment section that has been addressed in the parliament during question time, as well as tips about relevant news stories in local media that the party wants to react on, thus creating additional media attention. The interaction with the users and potential voters is what the FrP calls a "very useful tool."

Siv Jensen (the party leader) reads through everything, but she does not have the capacity to answer everyone. She posts two updates daily, but she can only answer a few.

The Progress Party

\section{Relating to editorial media through social media}

According to the SD, the internet and social media were in reality their only communication channels before the 2010 parliamentary election, except for regions such as Skåne (southern Sweden), where media were more positive towards the party, according to the SD. The 2010 election changed everything when SD secured 20 representatives in the parliament Riksdagen:

Now, we are a party represented in the Riksdagen. They cannot argue that we are a tiny party any more, we are for real. Also in a democratic perspective it is hard to refuse us. Swedish news media are struggling and we have a good campaign budget, it makes us more interesting. And we hope that we, just like the Danish People's Party and the Norwegian Progress Party, will become normalized, that we will become part of the establishment and accepted by media in a different way. It is a process, but it moves forward.

The Sweden Democrats

Social media is effective for the SD to reach out to a lot of people with the message, in their own framing. TV is still the place where the party reaches most people, but before the 2010 election, the party was not allowed to participate in televised election debates.

We can only hope that journalists will report what we say, that they don't misunderstand or distort things. We cannot comment and correct everything media writes about us. It would take too much time. We often find that what is said about us in Swedish media is outright wrong or framed wrongly.

Sweden Democrats 
The SD mentions one particular aspect where the integration between social and traditional media can be effective: When the party sometimes succeeds to get opinion pieces published in editorial media, it gives a good spread on social media.

We can see our own words in other places than our own fora. It gives more legitimacy. If the piece is good, we will link to it on Facebook, to show that we are present in other places as well. It helps us in the normalization process.

The Sweden Democrats

The FrP has noticed that many stories are developing on social media before they hit editorial mass media. The FrP argues that social media has an equal agenda-setting function as mass media. Nevertheless, most of the stories originating from social media are "someone says something stupid on social media," according to the FrP. They are aware how public and open social media and particularly Facebook is, even though many people and even politicians have private profiles. Additionally, the FrP also generates editorial coverage when the party leader publishes a Facebook post with new information. But social media also have their disadvantages:

Social media does not work well if you want to communicate a long, coherent message. If we write long and wordy updates, people will not read them. That balance - how to reach out to people and still communicate some substance - is hard to achieve with so few words. The substance might get lost. But if we set the agenda, we often get the chance to explain and expand, so I don't feel that social media has a clear disadvantage because of this.

The Progress Party

\section{The Facebook posts in light of the populist communication logic}

Next, in order to examine what characterizes the Facebook posts of the two Nordic right-wing parties during the election campaign, I have conducted a content analysis of the posts. Populist communication logic is empirically employed and the posts are coded in light of this framework.

First, regarding content (expressed as popular sovereignty, people-centrism, antielitism and exclusion of "others"), I find that people-centrism and anti-elitism most frequently occur among the Norwegian FrP, while exclusion of others and antielitism are more typical content in the posts by the SD. Exclusion of others is here understood in terms of a strict immigration policy to reduce the number of immigrants entering the country and returning existing immigrants and asylum seekers, and somewhat surprisingly, FrP only mentions immigration or strict immigration policy three times in the posts, while the SD mentions the topic eight times. Here is one example where the FrP mentions major issues, but not immigration: 
You can vote in advance up until Friday! Siv Jensen and the FrP need your support to demand new roads without tolls, reducing bureaucracy, lower fees for ordinary people and increased support for the police [3.09.2013].

It is also worth mentioning that the FrP uses terms such as a "strict immigration policy" and "sustainable immigration," while the SD, on the other hand, often talks about "mass immigration." A major difference between the FrP and the SD is that the FrP mentions many policy areas (i.e., transport, taxes, elderly, health), while the SD is mainly talking about immigration and criticism of political opponents and the media. Here is one post where the SD discusses both the media and immigration:

Swedish media are not directly known for inviting factual debate about immigration. Now it seems they are not even interested when they get paid to publish comparative and factual statistics on the issue. The Sweden Democrats' election campaign has been hindered by censorship and an advertising boycott. Where is the fear of reality coming from? [4.09.2014]

Second, turning to messenger, the (charismatic) leader is mentioned, but not as frequently as expected, based on populism literature (i.e., Canovan, 1999, p. 6). None of the leaders are mentioned as magnetic or larger-than-life figures, but both Siv Jensen (FrP, mentioned in 19 posts) and Jimmie Åkesson (SD, mentioned in 11 posts) are complimented for their campaign efforts. Åkesson in particular is praised for his ability to, as described by the party, stand tall during campaigns against him, advertising boycotts, and attempts at character assassination and for surviving the longest election campaign in the party's history (13.09.14). Siv Jensen is, among other things, praised for her "fantastic efforts" in different debates with opponents from the Labor party $(7.09 .13 ; 13.08 .13 ; 7.08 .13)$.

Third, regarding what form (expressed as negativity, simplicity, emotionalization) the posts are characterized by, a clear difference is found between the FrP and the SD. While the FrP mainly writes positive posts, advocating their policy, the SD writes more negative posts about political opponents, the media and the state of the Swedish nation. One could argue that most posts on Facebook are characterized by simplicity because of their short length. But simplicity can indicate something else than the length of posts, rather it can be characterized as a simple way of explaining complicated matters. Nevertheless, few of the posts are even trying to elaborate on complicated matters and situations. Most of the posts are short, encouraging posts aimed to motive the parties' supporters, which brings us to the fourth element: motives and aims (expressed as mobilization, power, legitimization).

Mobilization is the reoccurring motive and aim among both parties. Primarily the parties' own voters aim for mobilization, as expressed through the SD's use of the term "Sweden friends." 
"Sweden friends" indicates both friends of the party as well as friends and protectors of the nation. Similarly, the FrP is using the Facebook post to encourage their supporters to vote for them, to call a friend, drive someone to the voting booth, to watch the party leader in the televised debates, and to like and share FrP's Facebook post with their friends. On the other hand, I found five posts by the SD that are expressions of legitimation, as expressed in this post:

Half the people think it is time for the other parties to start cooperating with us! (link to poll).

This is the post that received most shares in total of all the posts (3,347 shares) as well as the most likes (16,419 likes). Power is clearly expressed in only one of the posts, this time from the FrP:

The FrP will perform a strong and just asylum and immigration policy. Voters who want to challenge today's immigration policy must make sure that the FrP becomes strong in order for us to gain power to introduce highly needed austerity measures.

Mobilization is thus the dominating motive and aim among these two parties on Facebook, while legitimization of their position and policy also occurs among the SD's updates.

In order to compare the social media strategies expressed through interviews as well as how this strategy is expressed through the content, Facebook engagement data is used to measure the followers' response on Facebook.

\section{Facehook engagement data}

The engagement data from the two parties' Facebook pages will be used to address how strategic social media practice is received by the followers of the two parties on Facebook. Contrasting strategy and practices in political parties' social media performance has proved fruitful in previous research (Kalsnes, 2016b). As expressed in the table below, the two parties have a similar frequency in the number of updates (Facebook posts) during the six weeks of data collection.

The SD had almost twice the number of fans $(85,250)$ compared to the Norwegian FrP $(47,152)$. Nevertheless, the SD do not have twice as much activity and interaction as the FrP, with one exception. While the difference in number of likes and comments is minimal, the number of shares on the SD's Facebook page $(21,463)$ is almost double compared to the FrP $(12,462)$. Apparently, the SD's strategy to encourage shares among their fans is working, which is also reflected in the average numbers of shares per post. 
Table 2. Data from the Facebook pages of the Progress Party (FrP) and the Sweden Democrats (SD)

\begin{tabular}{|l|c|c|}
\hline \multicolumn{1}{|c|}{ Facebook engagement data } & FrP & SD \\
\hline Number of Facebook fans & 47,152 & 85,250 \\
\hline Number of Facebook posts & 57 & 56 \\
\hline Total number of likes & 155,017 & 190,792 \\
\hline Average number of likes per post & 2,719 & 3,407 \\
\hline Total number of shares & 12,624 & 21,463 \\
\hline Average number of shares per post & 221 & 383 \\
\hline Total number of comments & 9,226 & 13,648 \\
\hline Average number of comments per post & 162 & 244 \\
\hline Total number of comments by page owner & 1,001 & 2 \\
\hline
\end{tabular}

Data collected between August 1-September 12, 2013 (FrP) and August 1-September 14, 2014 (SD). ${ }^{1}$

Source: Author.

As mentioned earlier, the SD has a higher number of fans $(85,250)$ compared to the FrP $(47,152)$. Based on these numbers, it is thus expected that the SD will achieve more likes and shares than the FrP. Nevertheless, when we divide the total number of likes by the number of fans, as well as the total number of shares by the number of fans, it is clear that FrP fans are more active than SD fans (see Table 3). Even though the SD has more fans, the FrP achieves more likes with fewer fans compared to the SD. ${ }^{2}$ When it comes to shares, FrP fans are sharing at the same level as SD fans, but because the SD has almost twice as many fans as the FrP, the $\mathrm{SD}$ achieve more shares on their posts.

Table 3. Likes and shares in relation to the number of followers

\begin{tabular}{|l|c|c|}
\hline & $\begin{array}{c}\text { Total number of shares based on } \\
\text { number of followers }\end{array}$ & $\begin{array}{c}\text { Total number of likes based on } \\
\text { number of followers }\end{array}$ \\
\hline FrP & 0.27 & 3.28 \\
\hline SD & 0.25 & 2.23 \\
\hline
\end{tabular}

Source: Author.

Additionally, we see that both the SD and FrP are practicing their strategy related to interactivity with users - understood here as comments from the page owner.

1 The FrP: https://www.facebook.com/fremskrittspartiet/?fref=ts (accessed: September 2013). The SD Facebook page was called "Sverigedemokraterna i riksdagen ja tack" (Sweden Democrats in the National Assembly - yes please); https://www.facebook.com/SDjatack/(accessed: September 2014). The page does not exist anymore.

2 The author is aware that posts on Facebook can be liked or shared by everyone on Facebook, not only fans of the FrP or the SD's page. Nevertheless, the mentioned numbers give some indications of the activity level of the FrP's, and SD's fans on Facebook. 
The FrP posted 1,001 comments or replies (as page owners), while the SD posted only two replies. In the interviews, the FrP expressed a clear intention to respond to potential voters in the comment section on Facebook, while the SD expressed a different and less enthusiastic attitude towards Facebook interaction, which is also confirmed by the Facebook data.

In the next section, I will further discuss these findings in light of the theoretical framework for this study.

\section{DISCUSSION, CONCLUSION AND FURTHER RESEARCH}

This study set out to address three research questions: (1) What kind of strategy do these parties have for social media and editorial media? (2) Are these parties' Facebook content characterized by populist communication logic? (3) What type of engagement are the parties achieving on Facebook? As the two parties under scrutiny are said to have different political roots as well as two different phases in the life cycle model of populist parties (Herkman, 2015; Stewart et al., 2003), we could expect the parties to use social media in different ways. As evident from the interviews, social media, and particularly Facebook is essential for the two parties, even more so for the SD. Social media, or rather Facebook, is regarded as an effective tool to get the parties' messages across to the electorate. The SD had problems getting an outlet for their messages outside of their own publications before the 2010 election, which secured them 20 representatives in the parliament Riksdagen. In what the SD describe as an unfriendly media landscape, social media has represented an alternative space where the party can spread the message, but the party is not prioritizing to communicate and interact with voters. While the $\mathrm{FrP}$ is using more of the interactive functions that social media allow for (Kalsnes \& Larsson, 2015), such as input via the comment section to address questions in the parliament, to comment on media coverage or to be in touch with supporters and voters, the SD are mainly using social media to broadcast and spread messages. The SD is less interested in participating in interactions with Facebook fans in the comment section, which the party thinks of as a space for supporters.

Nevertheless, the need for moderation in the comment section is acute for both parties. The FrP removes some comments, while the SD has a stricter moderation policy, deleting more heavy-handed comments that also criticize the party's policy, according to the interviews.

The focus on shares, which is regarded as giving more visibility and spread than likes, is even stronger within the SD than in the FrP. In order to create shares and likes and potential viral effects, both the parties stress the importance of using images combined with text in short, simple language, which apparently creates more engagement among users. Potential misunderstandings can be corrected when the party has set the media agenda and been invited onto TV or radio debates, according to the FrP. Moving on to editorial media vs. social media, both parties use social 
media to comment on news coverage in editorial news media. But since the SD has had a more conflicted relationship with Swedish media compared to the FrP's relationship with Norwegian media, social media is used as a tool to "normalize" the party. When the SD get opinion pieces published in editorial media, they share them on social media to get more attention, as well as to demonstrate that they got access outside of their own fora, which the SD explained was an important part of the legitimation and normalization process. The SD's "longing for normalization" is not expressed with the same intensity among the FrP, which can support Herkman's research that placed the $\mathrm{FrP}$ in the established phase and the SD in the insurgent phase in the life cycle model in the relationship between media and neo-populist movements (2015).

Regarding the extent of populist communication logic, we do see some traces of populist communication logic in the Facebook posting by the FrP and the SD, but it occurs rather randomly and inconsistently. First, the SD is in many ways communicating more in terms of populist communication logic compared to the FrP, both when it comes to content, form and motives. Particularly in regard to content, the SD frequently mentions topics relating to exclusion of others (immigrants) and anti-elitism (political opponents and the media). While the SD more frequently posts content about exclusion of others compared to the FrP, posts about people-centrism and anti-elitism appear on the pages of both parties. Part of the difference among the parties' Facebook postings can be explained by the parties' history and profile. While the FrP has profiled itself on a wider range of issues than immigration (such as transport, taxes, healthcare, security and elderly care), the SD is mainly known as an anti-immigration party (Raknes, 2012; Strömbäck et al., 2017). The different terms used by the two parties (the FrP advocating a strict immigration policy while the SD fights mass immigration), might also indicate national differences in Norway and Sweden. While Sweden has been one of the countries in Europe with the most liberal asylum laws (Swedish Migration Agency, 2018), Norway has had a much stricter immigration policy.

Secondly, the SD also uses a more negative form, compared to the FrP which often publishes positive posts, advocating their own policy. The SD has been treated as a "pariah party" by the other Swedish parties because of the party's neo-Nazi roots, the hostile environment around the party has been described as a "cordon sanitaire" where other parties have refused to cooperate with the SD (Strömbäck et al., 2017, p. 70). The negativity is clearly reflected in the party's Facebook posts.

Thirdly, the party leaders are fairly frequently mentioned in the two parties' Facebook posts (more often by the FrP), but not in an extraordinary way. They are mainly cherished for their campaigning efforts, which is also common among other political parties. Neither are described as particularly charismatic leaders, but as hard-working campaigners and debaters.

Fourth, both parties mainly use the Facebook posts for mobilization of their (existing) supporters. This can be explained by the time frame of the study (one 
month before the national election), when mobilization is of utmost importance. While we do see some posts that are expressions of legitimacy and power, they are in a clear minority of the posts.

As we see from the Facebook engagement data, the SD achieves more shares per post than the FrP. Nevertheless, we need to take into account that the SD has more fans of their Facebook page than the FrP, which is another explanation for the difference. Apparently, the SD's strategy to encourage shares among their fans is working, which is also reflected in the average numbers of shares per post.

This study has contributed with detailed insights into the understudied field of populist parties' political communication on social media. Differing from previous studies of political parties' social media strategy and practice (Kalsnes, 2016a), these two parties seem to more or less follow up their social media strategy in practice. The SD is mainly focused on spreading, thus broadcasting the message through likes and shares, which this study as well as other studies have proved that they are successful at (Larsson, 2017). The FrP is also aiming for viral shares of their messages, in addition to interaction with voters in the comment section, which they achieve to a high degree, also compared to other Norwegian parties (Kalsnes, 2016a). The SD are more closely communicating in terms of populist communication logic compared to the FrP.

This study has clear limits, as it has mainly focused on two parties among the Nordic populist parties. Future studies could look in more detail into the content and rhetoric of these parties' social media performances. Additionally, the character of Nordic populist parties' digital communities could be studied further to understand the demographic character of these emerging networked publics (Boyd, 2010).

\section{REFERENCES}

Aalberg, T., Esser, T., Reinemann, C., Strömbäck, J., \& de Vreese, C. (Eds.). (2017). Populist political communication in Europe. New York: Routledge.

Aardal, B., Krogstad, A., \& Narud, H. M. (Eds.). (2004). I valgkampens hete. Strategisk kommunikasjon og politisk usikkerhet [In the heat of the election campaign. Strategic communication and political uncertainty]. Oslo: Universitetsforlaget.

Albertazzi, D., \& McDonnell, D. (2008). Introduction: A new spectre for Western Europe. In D. Albertazzi \& D. McDonnell (Eds.). Twenty-first century populism: The spectre of Western European democracy (pp. 1-11). Basingstoke: Palgrave Macmillan.

Bjørgo, T., \& Gjelsvik, I.M. (2015). Forskning på forbygging av radikalisering og voldelig ekstremisme: En kunnskapsstatus [Research of prevention of radicalization and violent extremism: A research review]. Oslo: Politihøyskolen. Retrieved February 2, 2018, from https://www.regjeringen.no/contentassets/ dc64dbc441bc4a4db25f320eadd0d131/080615-forskning-pa-forebygging-av-radikalisering.pdf.

Boyd, D. (2010). Social network sites as networked publics: Affordances, dynamics, and implications.

In Z. Papacharissi (Ed.), Networked self: Identity, community, and culture on social network sites (pp. 39-58). New York: Routledge.

Canovan, M. (1999). Trust the people! Populism and the two faces of democracy. Political Studies, 47(1), 2-16.

Chadwick, A. (2013). The hybrid media system: Politics and power. Oxford: Oxford University Press. 
Engesser, S., Ernst, N., Esser, F., \& Büchel, F. (2016). Populism and social media: How politicians spread a fragmented ideology. Journal of Information, Communication \& Society, 20(8), 1109-1126.

Engesser, S., Fawzi, N., \& Larsson, A. O. (2017). Populist online communication: Introduction to the special issue. Information, Communication \& Society, 20(9), 1279-1292.

Enjolras, B., Karlsen, R., \& Steen-Johnsen, K., (2013). Liker, Liker Ikke [Like, dislike]. Oslo: Cappelen Damm.

Enli, G. S., \& Skogerbø, E. (2013). Personalized campaigns in party-centred politics. Information, Communication \& Society, 16(5), 757-774.

Gibson, J. J. (1979). The ecological approach to visual perception. Boston: Houghton Mifflin Harcourt.

Haanshuus, B. P., \& Jupskås, A. R. (2017). Høyreklikk! En analyse av ytre høyre på sosiale medier i Norge [Right click! An analysis of the right wing on social media in Norway]. Tidsskrift for samfunnsforskning, 58(2), 145-165. doi: 10.18261/issn.1504-291X-2017-02-01

Hallin, D. C., \& Mancini, P. (2004). Comparing media systems: Three models of media and politics. Cambridge: Cambridge University Press.

Herkman, J. (2015). The life cycle model and press coverage of Nordic populist parties. Journalism Studies, 18(4), 1-19.

Ihlebæk, K., Kalsnes, B., \& Simonsen, C. (unpublished work). Discussing immigration on social media: A study of politicians' facebook-pages during the migration crisis.

Jagers, J., \& Walgrave, S. (2007). Populism as political communication style: An empirical study of political parties' discourse in Belgium. European Journal of Political Research, 46, 319-345.

Jungar, A.-C., \& Jupskås, A. R. (2014). Populist radical right parties in the Nordic region: A new and distinct party family? Scandinavian Political Studies, 37, 215-238.

Jupskås, A., Ivarsflaten, E., Kalsnes, B., \& Aalberg, T. (2017). Norway: Populism from anti-tax movement to government party. In T. Aalberg, F. Esser, C. Reinemann, J. Strömbäck, \& C. de Vreese (Eds.), Populist political communication in Europe (pp. 54-67). New York: Routledge.

Kalsnes, B. (2016a). The power of likes: Social media logic and political communication. Dissertation at University of Oslo.

Kalsnes, B. (2016b). The social media paradox explained: Comparing political parties' Facebook strategy vs. practice. Social Media er Society, 15(2), 765-781.

Kalsnes, B., \& Larsson, A. O. (2015). Med makt til å like? Sosiale medier og politisk kommunikasjon. In Ø. Ihlen, E. Skogerbø, \& S. Allern (Eds.), Makt, medier og politikk: Norsk politisk kommunikasjon [Power, media and politics: Norwegian political communication] (pp. 219-232). Oslo: Universitetsforlaget.

Klinger, U. (2013). Mastering the art of social media. Information, Communication \& Society, 16(5), 717-736.

Koc-Michalska, K., Lilleker, D. G., \& Vedel, T. (2016). Civic political engagement and social change in the new digital age. New Media \& Society, 18(9), 1807-1816.

Kreiss, D. (2012). Taking our country back. New York: Oxford University Press.

Larsson, A. O. (2017). Going viral? Comparing parties on social media during the 2014 Swedish election. Convergence: The International Journal of Research into New Media Technologies, 23(2), $117-131$.

Larsson, A. O., \& Kalsnes, B. (2014). "Of course we are on Facebook": Use and non-use of social media among Swedish and Norwegian politicians. European Journal of Communication, 29(6), 653-667.

Lorentzen, D. G. (2014). Polarisation in political Twitter conversations. Aslib Journal of Information Management, 66(3), 329-341.

Mazzoleni, M. (2014). Mediatization and political populism. In F. Esser \& J. Strömbäck (Eds.), Mediatization of politics: Understanding the transformation of Western democracies (pp. 42-57). New York: Palgrave Macmillan.

Mudde, C. (2004). The populist Zeitgeist. Government and Opposition, 39, 542-563. 
Mudde, C., \& Kaltwasser, C. R. (2017). Populism: A very short introduction. Oxford: Oxford University Press.

Raknes, K. (2012). Høyrepopulismens hemmeligheter [The secrets of right-wing populism]. Oslo: Spartacus.

Reinemann, C., Aalberg, T., Esser, F., Strömbäck, J., \& de Vreese, C. H. (2017). Populist political communication: Toward a model of its causes, forms, and effects. In T. Aalberg, F. Esser, C. Reinemann, J. Strömbäck, \& C. de Vreese (Eds.), Populist political communication in Europe (pp. 12-25). New York: Routledge.

Stewart, J., Mazzoleni, G., \& Horsfield, B. (2003). Power to the media managers. In G. Mazzoleni, J. Stewart, \& B. Horsfield (Eds.), The media and neo-populism: A comparative analysis (pp. 217239). London: Praeger.

Strömbäck, J., Jungar, A. C., \& Dahlberg, S. (2017). Sweden: No longer a European exception. In T. Aalberg, F. Esser, C. Reinemann, J. Strömbäck, \& C. de Vreese (Eds.), Populist political communication in Europe (pp. 68-81). New York: Routledge.

Strömbäck, J., Ørsten, M., \& Aalberg, T. (2008). Communicating politics: Political communication in the Nordic countries. Göteborg: Nordicom.

Skogerbø, E., \& Krumsvik, A. H. (2015). Newspapers, Facebook and Twitter. Journalism Practice, 9(3), 1-17.

Swedish Migration Agency. (2018). Migration to Sweden. Retrieved November 10, 2018, from https:// www.migrationsverket.se/English/About-the-Migration-Agency/Migration-to-Sweden/History. html.

TNS Gallup. (2016). Sosiale medier er blitt viktige i nordmenns kundereiser [Social media has become important for Norwegian customers]. Retrieved May 10, 2017, from https://kantar.no/ kantar-tns-innsikt/sosiale-medier-er-blitt-viktige-i-nordmenns-kundereiser/.

UiO. (2013). Extract status-posts and comments from public Facebook pages. Retrieved September 10-11, 2013, from http://www.uio.no/tjenester/it/forskning/kvalitativ/fb_loader/. 